\title{
Breeding biology and biometrics of Myiozetetes c. cayanensis (Aves: Tyrannidae) in southwest Brazilian Amazonia with breeding season in Brazil
}

\section{Biología reproductiva y biometría del Myiozetetes c. cayanensis (Aves: Tyrannidae) en el suroeste de la Amazonia brasileña y el período reproductivo en Brasil}

\author{
Jônatas Lima * \\ https://orcid.org/0000-0002-9663-5208 \\ jonatasornito@gmail.com

\section{Edson Guilherme} \\ https://orcid.org/0000-0001-8322-1770 \\ guilherme.edson@gmail.com

\section{* Corresponding author} \\ Laboratório de Ornitologia, Centro de Ciências Bio- \\ lógicas e da Natureza, Universidade Federal do Acre, \\ Rio Branco, AC, Brazil.

\section{Citación} \\ Lima J, Guilherme E. 2021. Breeding biology and bio- \\ metrics of Myiozetetes c. cayanensis (Aves: \\ Tyrannidae) in southwest Brazilian Amazo- \\ nia with breeding season in Brazil. Revista \\ peruana de biología 28(3): e20475 (Agosto \\ 2021). doi: http://dx.doi.org/10.15381/rpb \\ v28i3.20475
}

\section{Presentado: $\quad$ 14/09/2020 \\ Aceptado: $\quad$ 26/04/2021 \\ Publicado online: $30 / 08 / 2021$}

Editor:

Leonardo Romero

\section{Resumen}

Nuestro estudio proporciona información sobre la reproducción y la biometría del bienteveo alicastaño Myiozetetes cayanensis en el suroeste de la Amazonia brasileña. M. cayanensis se distribuye desde América Central hasta el norte de América del Sur. Realizamos observaciones sobre la reproducción y captura de esta especie en un fragmento de bosque de tierra firme en el estado de Acre, entre 1999 y 2020 y evaluamos la época de reproducción en Brasil mediante datos de ciencia ciudadana. Monitoreamos nueve nidos entre 2012 y 2020 , construidos a una altura promedio de $1.8 \mathrm{~m}$ sobre el suelo. El tamaño de la puesta fue de dos, tres o cuatro huevos, incubados durante 15 días. Monitoreamos el desarrollo de seis polluelos: el peso mínimo al nacer fue de $2 \mathrm{~g}$ y los polluelos con una masa media de $c a .25 .5$ g. La tasa de crecimiento constante $(K)$ de los polluelos fue de 0.18 con una asíntota de crecimiento de $22.8 \mathrm{~g}$. La tasa de supervivencia diaria fue del $90 \%$ y $100 \%$ durante los períodos de incubación y cría, respectivamente. El éxito de Mayfield en los períodos de incubación y cría fue de 20 y $100 \%$, respectivamente. El éxito aparente de anidación en los períodos de incubación y polluelo fue de 46 y $100 \%$, respectivamente. Registramos una longevidad mínima de 2 años, nueve meses y 26 días. La subespecie $M$. c. cayanensis comienzan a anidar principalmente entre la estación seca y lluviosa en Brasil, superponiéndose con el período de muda en el suroeste de la Amazonia.

\section{Abstract}

Our study provides information on the breeding and biometrics of Rusty-Margined Flycatcher Myiozetetes cayanensis in southwest Brazilian Amazonia. M. cayanensis is distributed from Central America until north of South America. We made observations on reproduction and captures of this species in a terra firme forest fragment in the state of Acre, between 1999 and 2020 and we evaluated the breeding season in Brazil through citizen science data. We monitored nine nests between 2012 and 2020 , built at a mean height of $1.8 \mathrm{~m}$ above ground. Clutch size was two, three or four eggs, incubated for 15 days. We monitored the development of six nestlings: minimum hatch weight was $2 \mathrm{~g}$ and young fledged with a mean mass of $c a .25 .5$ g. The constant growth rate $(K)$ of nestlings was 0.18 with a growth asymptote of $22.8 \mathrm{~g}$. Daily survival rate was $90 \%$ and $100 \%$ during the incubation and nestling periods, respectively. The Mayfield success in the incubation and nestling periods was 20 and 100\%, respectively. Apparent nesting success in the incubation and nestling periods was 46 and $100 \%$, respectively. We recorded a minimum longevity of 2 years, nine months and 26 days. The subspecies $M$. c. cayanensis start to nest mainly between the dry and rainy season in Brazil, overlapping with the molt period in southwest Amazonia.

Palabras clave:

Myiozetetes cayanensis; bienteveo alicastaño; biología reproductiva; tamaño de nidada; polluelos; morfometría de aves; datos de ciencia ciudadana.

\section{Keywords:}

Myiozetetes cayanensis; Rusty-margined Flycatcher; breeding biology; Clutch size; nestlings; bird morphometrics; citizen-science data. 


\section{Introduction}

Contributions to the conservation of bird species are possible with studies of the reproductive biology which reveal important data that can aid understanding of ecological relationships (Martin 2004) between biotic and abiotic factors. In the Neotropical region ornithological studies have increased considerably in recent years (Xiao et al. 2017), but the basic aspects of the biology of many bird species remain limited. Among them are reproductive aspects, mainly knowledge about nests and eggs, mainly Flycatchers (Heming et al. 2013). The availability of food resources influences the start of a breeding season (Sick 1997) and combination with choice of nest site and time invested in parental care are crucial for the survival of nestlings (Saether 1985, Mezquida \& Marone 2001).

Rusty-Margined Flycatcher ranges from Costa Rica and Panama to northern South America (Mobley \& Kirwan 2020). This species is usually one of the most common flycatchers in the regions of Brazil in which it occurs (Sick 1997). Four subspecies have been described, two of which occur in Brazil: Myiozetetes cayanensis cayanensis and Myiozetetes c. erythropterus (Piacentini et al. 2015). Myiozetetes c. cayanensis is relatively widely distributed in Brazil in comparison with M. c. erythropterus, which is restricted to southeastern Brazil (Mobley \& Kirwan 2020). Few data are available on the reproductive biology of $M$. cayanensis (Carvalho 1960, Oniki \& Willis 1983, Dyrcz 1991, Pascoal et al. 2016), and most of the studies have been conducted in countries other than Brazil (Mobley \& Kirwan 2020). In the present study, we obtained detailed data on the reproductive biology and biometrics of M. c. cayanensis from a lowland terra firme forest in southwest Brazilian Amazonia, including its breeding season in Brazil, which provide important insights into the life history patterns of the flycatchers.

\section{Material and methods}

We conducted this study at the Zoobotanical Park of the Federal University of Acre (UFAC), in Rio Branco, capital of the Brazilian state of Acre. The Zoobotanical Park $\left(09^{\circ} 57^{\prime} 08.9^{\prime \prime} \mathrm{S}, 67^{\circ} 52^{\prime} 22.5^{\prime \prime} \mathrm{W}\right)$ is a forest fragment with an area of $c a .100$ ha surrounded by an urban matrix. It is considered to be one of the largest urban forest fragments of the Rio Branco (Meneses-Filho et al. 1995). The vegetation is composed of successional forests of varying ages dominated by the cycle of mass mortality and succession of the bamboo Guadua weberbaueri, and dense understory with many vine tangles (Meneses-Filho et al. 1995, Silveira 1999). The region's climate is humid tropical, with a dry season (May-October) and a rainy season (November-April) (Duarte 2006). The avian assemblage of the ZP is composed by 150 birds species distributed over 36 families, and some species are migratory and others have restricted geographical distribution (Guilherme 2001).

We found the nests during non-systematic observations made between 2012 and January 2020. We monitored all nests found, irrespective of stage, until they became inactive. We measured eggs and nestlings using a millimeter ruler and analogue (2012-2014) or digital callipers accurate to $0.01 \mathrm{~mm}$ (2015-2020). We weighed eggs and nestlings using a Pesola ${ }^{\circledR}$ scale with a capacity of $100 \mathrm{~g}$ and accurate to the nearest $1 \mathrm{~g}$ (2012-2014) or a digital scale accurate to $0.05 \mathrm{~g}$ (2015-2020). We collected nests after they became inactive and deposited them in the collection of the UFAC ornithology laboratory. Nests were described according to the standardized scheme proposed by Simon and Pacheco (2005).

We trapped and ringed Rusty-Margined Flycatcher in the years 1999-2002 (1624.8 net / hours), 2004-2006 (1367.3 net / hours) and 2009-2019 (57948.2 net / hours). We used $12.0 \times 2.5 \mathrm{~m}$ mist-nets with $36 \mathrm{~mm}$ mesh and banded individuals with numbered metal rings supplied by CEMAVE (Centro Nacional de Pesquisa e Conservação de Aves Silvestres), under the scope of project 1099 , coordinated by EG (senior bird bander, reg. no. 324654). We collected morphometric data (wing, tarsus, bill, head, tail, total length and cloacal temperature) only from 2002 following the protocol outlined by Proctor and Lynch (1993).

In general, we used a Pesola ${ }^{\circledR}$ scale with a capacity of $100 \mathrm{~g}$ ( $1 \mathrm{~g}$ precision) to weigh birds and nestlings prior to 2014 , and a digital scale ( 0.05 g precision) during 2015-2020. We used a millimetre ruler to measure wing, tail and total length, and analogue callipers $(0.05$ $\mathrm{mm}$ precision) until 2014 and digital callipers $(0.01 \mathrm{~mm}$ precision) in 2015-2020 to measure bill and tarsus. For each biometric, data were taken from each adult and juvenile individual only the first it was trapped. During ringing, we distinguished adults and juveniles based on the presence of juvenile plumage (see Sibley 2010, Johnson et al. 2011). We examined each trapped individual to determine molt in the remiges and rectrices (Sibley 2010) and presence or absence of a brood patch (Redfern 2010), and we included only adults in the analysis. We measured cloacal temperature with a digital thermometer $\left(32.0-42.9{ }^{\circ} \mathrm{C}\right.$, accurate to $0.1{ }^{\circ} \mathrm{C}$ ) and calculated minimum longevity from the first day an individual was banded to their last recapture (Scholer et al. 2018).

We searched for records of active Myiozetetes cayanensis nests, irrespective of subspecies, including those with nestlings, up to June 5th 2020, on the Brazilian Wikiaves site (Wikiaves 2020). We verified the date, location (Brazilian state and municipality), the author, and the content of each photograph (nests with eggs or nestlings). For the purposes of the study, we considered all the photographs from all localities, except those of a given nest taken on the same or subsequent days. We compiled a list of the number of records per month over the course of the year, including active nests and nests with nestlings, to determine the period of the species' breeding season in Brazil, in general. Citizen science plays an especially important role in the compilation of data on the natural history of bird species (Tewksbury et al. 2014, Turnhout et al. 2016).

We calculated the incubation period from the date the last egg was laid until the last chick hatched. Post-hatching, we measured the mass of nestlings every two days to minimise our impact on nests. We banded young with a 
numbered metal ring while still in the nest. We considered the nestling development period based on the hatching of the first nestling and the abandonment of the nest by the second chick. The day of hatching was treated as day 0 (Oniki \& Willis 2001). For nests found with nestlings, we estimated age based on the mass of the nestlings, comparing them with data for young monitored from hatching. We applied the equation proposed by Ricklefs (1967) to determine the growth rate of the nestlings:

$$
W(t)=A /(1+e[-K(t-t i)]
$$

where $W(t)$ is the mass of the nestling at age $t, A$ is the asymptote of the growth curve, $K$ is the constant growth rate and $t i$ is the inflection point of the growth curve. We ran the equation in the $\mathrm{R}$ software, version 3.5.1 (R Core Team 2018). We used the Mayfield (1961) method to calculate reproductive success rates, and determined apparent success as the ratio between the number of successful nests and the total number found (Jehle et al. 2004).

\section{Results}

We found nine Rusty-Margined Flycatcher nests, which all were active (three in January, February, and March 2013, two in August and December 2014, one in January and two in August 2015, and one in January 2015). All nests were constructed in open areas near water. Six nests were built in support plants above water (Fig. 1a, and three nests were built near wasps colonies in lemon tree Citrus sp. (Rutaceae) (Fig. 1b). On average, nests were placed $1.80 \mathrm{~m}$ above ground (range 1.43-2.15 $\mathrm{m})$. We found four nests under construction, three with eggs (two of which had been abandoned), one with nestlings, and one was inaccessible. All nests were built of most pliable dry grass, few fine woody steams (thickness $2.01 \mathrm{~mm}$ ), roots, and dry leaves. Internally, dry grass arranged irregularly (Fig. 1c). In one nest we found string thread. In other nest we found pieces of plastic and crochet string too in its external lining. All nests conformed to the closed / globular / fork types (Fig. 1d), arranged in two to six thin branches from the main branch. We present mean measurements of nests $(n=3)$ in Table 1 .
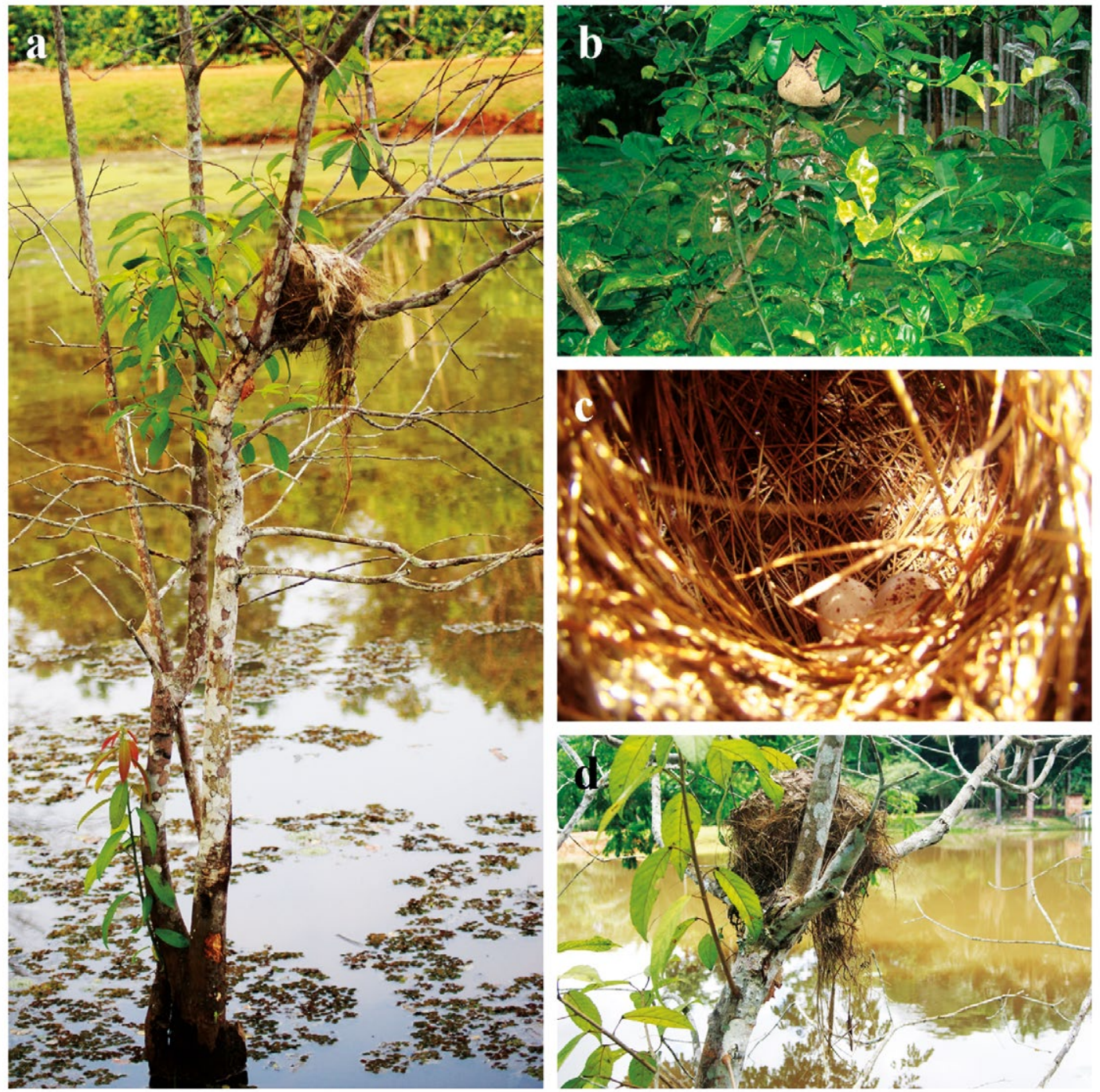

Figure 1. Rusty-Margined Flycatcher Myiozetetes $c$. cayanensis nests found in a terra firme forest fragment in southwest Amazonia. (a) Nest built $1.43 \mathrm{~m}$ above water; (b) Nest built near wasps colonies; (c) internal view of nest characteristics; and (d) lateral view of an nest sited in fork. All photographs by JL. 
Table 1. Characteristics of Rusty-Margined Flycatcher Myiozetetes c. cayanensis nests $(n=3)$ found between 2012 and 2020, in a terra firme forest fragment in Acre, Brazil, southwest Amazonia.

\begin{tabular}{lcccc}
\hline \multirow{2}{*}{ Measurements } & Mean & SD & \multicolumn{2}{c}{ Range } \\
\cline { 5 - 6 } & & & Min & Max \\
\hline Height above the ground $(\mathrm{m})$ & 1.8 & 0.3 & 1.43 & 2.15 \\
height of the external wall $(\mathrm{mm})$ & 156.3 & 33.5 & 123 & 190 \\
wall thickness $(\mathrm{mm})$ & 28.6 & 6.0 & 24.5 & 35.4 \\
Entrance hole diameter $(\mathrm{mm})$ & 58.1 & 9.7 & 50.4 & 69 \\
Deep $(\mathrm{mm})$ & 30.6 & 26.5 & 0 & 46 \\
Circumference $(\mathrm{cm})$ & 48.2 & 10.0 & 37.7 & 57.6 \\
\hline
\end{tabular}

In four nests the clutch size was two eggs, in two nests was three eggs, and in one nest was four eggs. Eggs were predominantly white with pale and dark brown blotches, generally concentrated at the larger end (Fig. 2a). Mean egg mass was $2.8 \pm 0.5 \mathrm{~g}$ (range 2.0-3.5 g; $\mathrm{n}=$ 13 ) and size $21.8 \pm 1.2 \times 15.4 \pm 0.5 \mathrm{~mm}$ (range $21-25 \times$ $15-16 \mathrm{~mm}$ ). Of all the nests monitored with eggs, in only one nest three of the four eggs failed to hatch. Incubation period was 15 days. Daily nest survival showed that there is $100 \%$ chance that a nest will fledge at a least one juvenile. Daily survival rate during the incubation period was $90 \%$. Assuming an incubation period of 12 days, Mayfield success was 20\%, and apparent success was $46 \%$ during the incubation period.

We monitored the development of six nestlings in three nests (three nestlings in nest 4 from September to October 2014, one nestling from nest 5 in January 2014, and two nestlings from nest 9 in Janury 2020). Nestlings hatched with light pink skin, few plumes on the back and head, and eyes closed (Fig. 2b). After five days, the eyes are slightly open, and the feathers of the remiges and rectrices start to develop (Fig. 2c). We monitored three nestlings from hatching.
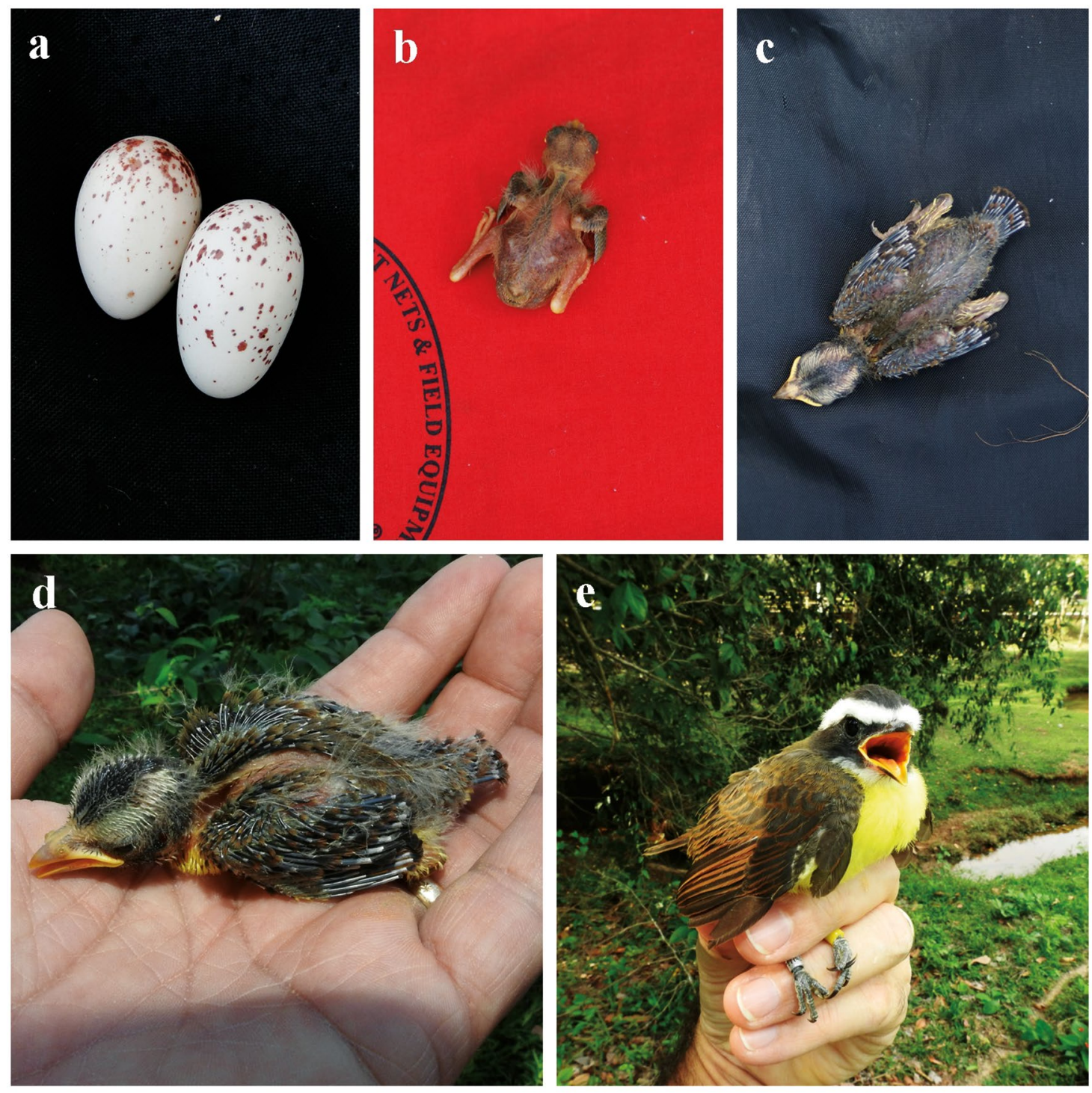

Figure 2. Development of Rusty-Margined Flycatcher Myiozetetes c. cayanensis nestlings in a terra firme forest fragment in southwest Amazonia. (a) detail of the eggs, (b) recently hatched nestling, and (c) five-day-old nestling (Nest 2, Figure 2); (d) 14-day-old and (e) 23-day-old nestling (nest 3, Figure 2). (Photos a, b and c by JL; $d$ and e by EG). 
Mean hatch weight was $2.3 \pm 0.58 \mathrm{~g}$ (range $2-3 \mathrm{~g} ; \mathrm{n}=$ $3)$ and nestling weight average $20 \mathrm{~g}(\mathrm{n}=6)$ after 14-16 days, and $25.5 \mathrm{~g}(\mathrm{n}=3)$ on day 23 (Fig. $2 \mathrm{~d}$, e), the oldest age recorded of any nestling (Fig. 3). Two chicks fledged after 22 days, while four chicks fledged after 23 days (Fig. 3 ). We ringed all chicks in the nest (ring codes F51460, F51463, F51454, F51492, F67598 and F77742). In two nests all nestlings were infected with maggots under skin on the head. No nestling monitored was predated after hatching. The longest nestling period was 23 days and chicks fledged at a mean mass of $24.2 \pm 1.3 \mathrm{~g}$ (range 22-25.5 g; $\mathrm{n}=6$ ).

The constant growth rate $(K)$ of the nestlings was 0.18 (range 0.02-0.14; $\mathrm{SE}=0.03$ ) with a growth asymptote of 22.8 g (26.99-29.71 g; SE = 6.9; Fig. 3). Daily survival for nestling period was $100 \%$. Mayfield success during the nestling period was $100 \%$, assuming chicks remained in the nest for 23 days. Apparent success was 100\% in the nestling period.

We trapped adults $(\mathrm{n}=67)$ and young individuals ( $\mathrm{n}$ $=38$, including re-captures) in all months of the year except in August. During all years monitored, most of young individuals were captured between January and March and in October ( $n=24$; Fig. $4 a)$. We found active nests in January-March, August, and December (Fig. 4a), and we recorded individuals with brood patch between August and April ( $n=23$; Fig. $4 a)$ and in June $(n=1)$ while we recorded majority of moulting individuals from September to May (n=62; Fig. 4a).

We obtained 28 citizen science records of active nests of Rusty-Margined Flycatcher (two of which contained nestlings) between 2008 and 2019 from 11 of the 26 Brazilian states, as well as the Federal District. Photographs of active nests were found in all months of the year except for March (Fig. 4b), although most records $(53.5 \%$; $n=15)$ were obtained between September and November (Fig. 4b). Most records $(n=13)$ were from Brazil's North region, with eight from the Midwest and seven from the Southeast region.

We recorded morphological information of $93 \mathrm{M}$. $\mathrm{ca}$ yanensis individuals trapped between 2002 and 2019. Measurements of individuals were: weight $27.7 \pm 4.4 \mathrm{~g}$ (range 20-52.4, $\mathrm{n}=93$ ); wing $87.7 \pm 4.9 \mathrm{~mm}$ (range 78$107, \mathrm{n}=93$ ); tarsus $18.7 \pm 2.9 \mathrm{~mm}$ (range $11.5-26.6 \mathrm{~mm}$, $\mathrm{n}$ =92); bill $14.6 \pm 1.6 \mathrm{~mm}$ (range $10-17 \mathrm{~mm}, \mathrm{n}=56$ ); head size $34.6 \pm 2.5 \mathrm{~mm}$ (range $27.9-37 \mathrm{~mm}, \mathrm{n}=11$ ); tail $70.8 \pm 7.4 \mathrm{~mm}$ (range $45-98 \mathrm{~mm}, \mathrm{n}=93$ ); total length $174.3 \pm 8.1 \mathrm{~mm}$ (range $149-191 \mathrm{~mm}, \mathrm{n}=79$ ) and cloacal temperature $40.9 \pm 1.5^{\circ} \mathrm{C}$ (range $39.6-42.9^{\circ} \mathrm{C}, \mathrm{n}=4$ ).

We observed longest live time from 119 captures and ringed and posterior recaptures of 22 individuals between 1999 and 2019. Of the ringed individuals, 90.9\% were recaptured more than once $(n=20)$. Longest minimum longevity was recorded for individual F16643 banded as an adult on 12 February 2014 and last re-trapped on 8 December 2016 (two years, nine months and 26 days, or 1,034 days after banding). Three other longestlived individuals were F16621, banded on 12 February 2014 and re-trapped on 21 June 2016 (two years, four months and 26 days, or 878 days after banding), F26529 banded on 26 March 2014 and re-trapped on 16 August 2016 (two years, four months and 21 days, or 873 days after banding) and F16621 banded on 12 February 2014 and re-trapped on 21 June 2016 (two years, four months and 9 days, or 861 days after banding). We re-trapped the individuals E61472, F26592, F36397, and F51497 all after one year (378-572 days) and the other 12 individuals at intervals of $<1$ year (2-154 days).

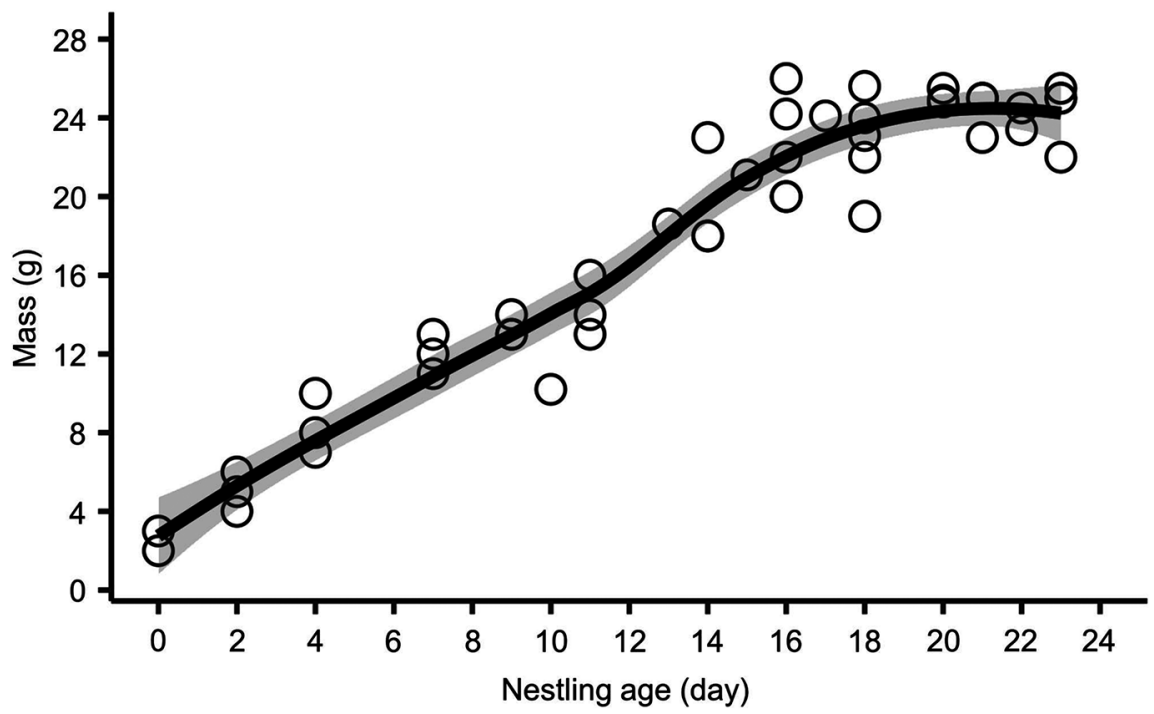

Figure 3. Logistic growth curve for six nestlings of Rusty-Margined Flycatcher Myiozetetes c. cayanensis, monitored in a terra firme forest fragment in southwest Amazonia between 2012 and 2020. Each circle represents a different nestling. 

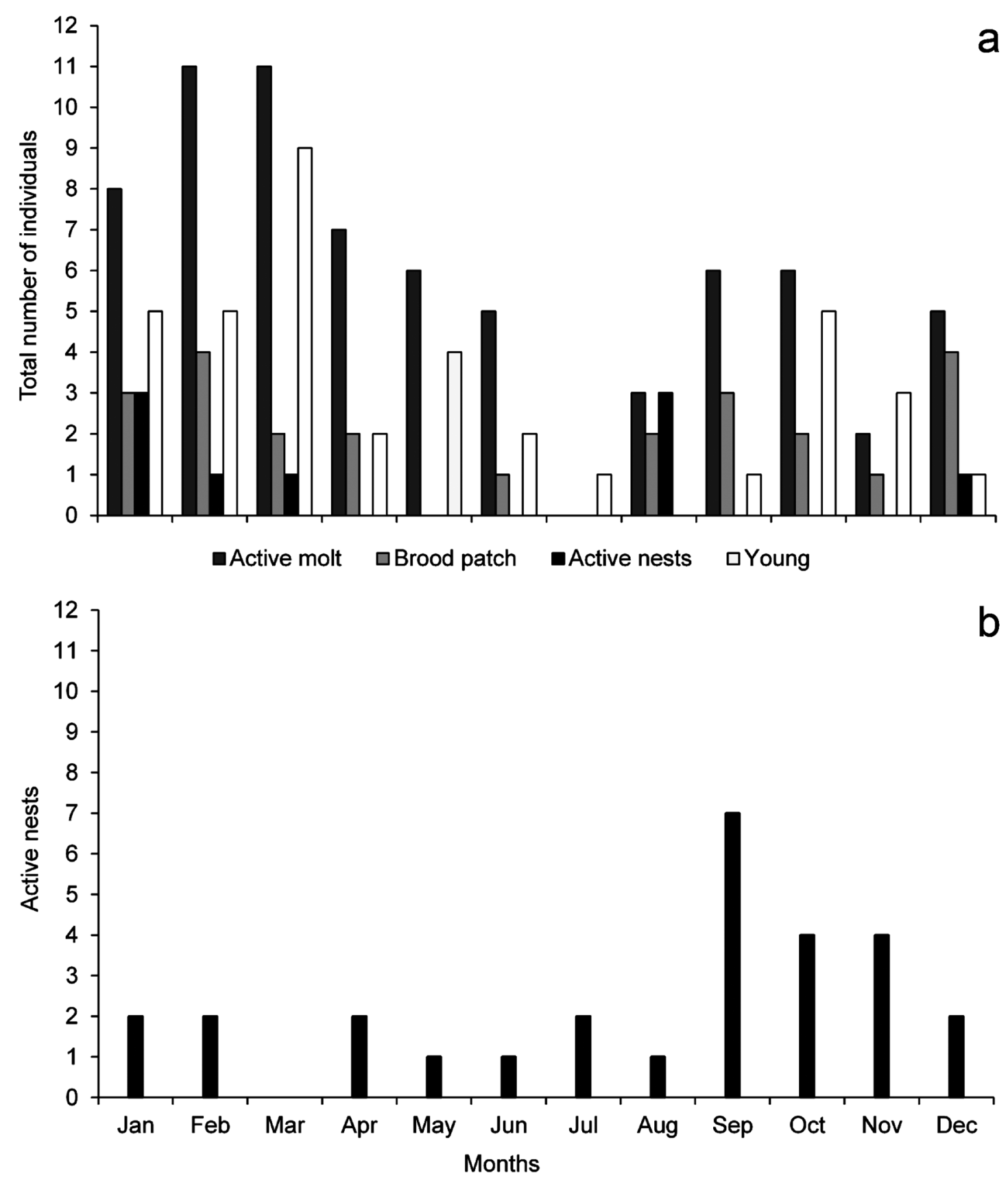

Figure 4. (a) Rusty-Margined Flycatcher Myiozetetes c. cayanensis trapped during the study period in a fragment of terra firme forest in southwest Amazonia in 1999-2002, 2004-06 and 2009-19, and active nests during 2012 to 2020. The bars show the numbers of ringed juveniles, molting, the presence of vascularized brood patches and active nests. Re-traps are not shown; (b) Monthly distribution of 28 active nests of Rusty-Margined Flycatcher Myiozetetes c. cayanensis in 11 Brazilian states between 2008 and 2019 . Source: Wikiaves (www.wikiaves.com.br).

\section{Discussion}

Myiozetetes cayanensis is resident and common in the Zoobotanical Park and campus of the Federal University of Acre in Rio Branco (Guilherme 2001), where the specie is found typically at the forest edge and in open areas, most often near bodies of water. The eastern extreme of the Brazilian state of Acre and adjacent areas of the lowlands of southeastern Peru and northeastern Bolivia represent the limit of the distribution of $M$. cayanensis in southwestern Amazonia (Schulenberg et al. 2010, Guilherme 2016, Mobley \& Kirwan 2020).
In fact, this is one of the few areas in the southwestern extreme of the Amazon basin where M. cayanensis occurs in sympatry with its congener, Social Flycatcher Myiozetetes similis (Guilherme 2016). This occurrence in sympatry should shape the reproductive behaviour of both species with respect to the construction and selection of the nest site, and we suggest a study to verify this hypothesis. The most detailed data on the reproductive patterns of $M$. cayanensis were obtained during studies in Panama (Skutch 1960, Ricklefs 1976, 1980, Dyrcz 2002), Guiana and Suriname (Haverschmidt 
1961, 1971), and northern Brazil (Oniki \& Willis 1983). In our study area, Rusty-Margined Flycatcher prefers to nest in open areas and uses plants located in sites with much human activity, like was also observed elsewhere in Amazonia (Pascoal et al. 2016, Oniki \& Willis 1983) and northern Venezuela (Verea 2018). The species constructs its nest low above ground or water level $(<1$ $\mathrm{m}$ ) and appears to prefer to nest near wasps colonies as reported in Panama (Dyrcz 2002). This undoubtedly reveals a defence mechanism against predators, because when nests were not built near wasps, they were built above water in our study area.

Nest shape was similar to those Myiozetetes c. hellmayri and M. c. cayanensis found in Panama (Dyrcz 2002) and Suriname (Haverschmidt 1971), respectively, and those found in Brazilian Amazonia (Oniki \& Willis 1983). This nest type is typical of many Tyrannidae, such as species of the genus Pitangus and Camptostoma (Sick 1997). Use of anthropogenic nest material to construct nests is not uncommon in M. cayanensis. In a Cerrado-Amazonia transition, in north Tocantins, Pascoal et al. (2016) reported that $M$. cayanensis used synthetic wool and plastic in their nests (Wikiaves data: WA1853400). As it is a species highly adapted to urban environments, the availability of suitable plant material may sometimes be insufficient for nest construction, which leads to the birds using material discarded by humans (Borges \& Marini 2010, Marini et al. 2012, Suárez-Rodriguez et al. 2017, Batisteli et al. 2020, Lima \& Guilherme 2020).

Clutch size and egg characters are similar to descriptions from Suriname, Panama (Hellebrekers 1942, Skutch 1960, 1985), Guiana (Haverschmidt 1961), Peru (Dyrcz 1991) and Ecuador (Solano-Ugalde et al. 2007) and those described in Brazil (Carvalho 1960). We recorded an incubation time similar to that reported in Suriname (16 days) (Haverschmidt 1971) and Pará, Brazil (14 days) (Carvalho 1960) using the same method of this last author. Incubation time was also equal to that Social Flycatcher in Panama (Skutch 1960). Therefore, we can expect an incubation period estimated from the egg-laying to the hatching of the last egg between 14 and 16 days. Nestling morphology and mass at hatching were similar to the data reported in Peruvian Amazon (Dyrcz 1991), where the nestlings remained in the nest for 21 days. This author reported that chicks fledged with a mass of $25.5 \mathrm{~g}$, similar to our findings. Regarding the growth rate of nestlings, ours are the first calculations for $M$. c. cayanensis. Our rate (0.18) was lower to the values calculated for four individuals of $M$. c. hellmayri and other flycatchers in Panama (0.37-0.41), but the growth asymptote was similar (Ricklefs 1976). Growth rate was also lower than that calculated for others Passeriformes at the same study site (Guilherme \& Lima 2019, Lima \& Guilherme 2020).

Contrary to observed in Panama, no nestlings infected with maggots in our study area were predated (Dyrcz 2002), but predation of Rusty-Margined Flycatcher nests has been observed in other localities. For example, in the Pantanal wetland $50 \%$ of the nests were predated, with a success rate of 25\% (Pinho \& Marini 2014) and in Suriname, a nest with eggs was predated by the Yellow-headed Caracara (Milvago chimachima) (Haverschmidt 1971). In our study we do not detected predation on nests, indicating that locally the species' nests do not appear to be heavily predated. Certainly, the construction of nests in sites with difficult access, such as above water level or near wasp colonies, can contribute to the reproductive success of Rusty-margined Flycatcher.

The sum of the evidence from long-term studies and occasional records on reproduction in Rusty-Margined Flycatcher indicates that this species nests preferentially at the onset of the rainy season (Skutch 1960, Ricklefs 1980, Sick 1997, Dyrcz 1991, 2002, Pinho \& Marini 2014, Pascoal et al. 2016), with active nests being observed only occasionally in other months of the year (Haverschmidt 1971, Oniki \& Willis 1983). In our study area, brood patches and active $M$. cayanensis nests begin to appear in the late dry season, that is, September, continuing throughout the rainy season (August-April) (Duarte 2006). Photographic records obtained through citizen science show that this pattern is typical of the rest of Brazil. That is, that the species begins to reproduce in transition from the dry to the rainy season, extending on through the rainiest months of the year (Gan et al. 2004). At the beginning of the rainy season, Rusty-Margined Flycatcher benefits from an abundant supply of insects (Kishimoto-Yamada \& Itioka 2015) to feed its young. The chicks ingest large amounts of beetle imagos and caterpillars (Dyrcz \& Flinks 2003). In the western Amazon, as well as in tropical forests, insects of the orders Coleoptera and Lepidoptera may both occur in greater abundance during the transition between the dry and rainy seasons than at other times of the year (Frith \& Frith 1985, Penny et al. 1978, Rodrigues 1992, Checa et al. 2009). Overlap molt was similar to data from Bran-coloured Flycatcher Myiophobus fasciatus and Euler's Flycatcher Latrotriccus euleri in south Brazil (Repenning \& Fontana 2011) and to that observed for Western Kingbirds Tyrannus verticalis in Oklahoma, USA (Jahn et al. 2017).

Variation in mean body mass for the species is consistent with one individual weighed in Amazonia Oriental (Silva et al. 1990). A comparison of the morphometric measurements (wing, tarsus and total length) between Social Flycatcher and Rusty-Margined Flycatcher in our study area did not reveal a significant difference capable of differentiating the two species by these parameters, however the average weight of both species was significantly different (Santos \& Guilherme 2017). The size of the head, bill, tail length and cloacal temperatures data had not previously been reported for Rusty-Margined Flycatcher. Regarding the longevity data, ours are the first calculations for this species. Our minimum longevity records were lower with the those available for other flycatchers, e.g. Slate-headed Tody Todirostrum sylvia (six years old) and Olive-striped Flycatcher Mionectes olivaceus (nine years old) in Venezuela (Lentino et al. 2003), and Slate-capped Flycatcher Leptopogon superciliaris (seven years old) in Peruvian Amazon (Scholer et al. 2018). Flycatchers in north America had been re- 
ported a variation in minimum longevity between 5-11 years old (Kennard 1975, Klimkiewicz \& Futcher 1989).

\section{Literature cited}

Carvalho CT. 1960. Comportamento de Myiozetetes cayanensis y notas biológicas sobre especies afins (Passeres, Tyrannidae). Pap. Avuls. Dep. Zool., São Paulo 14: 121132.

Checa MF, Barragán A, Rodríguez J, Christman M. 2009. Temporal abundance patterns of butterfly communities (Lepidoptera: Nymphalidae) in the Ecuadorian Amazonia and their relationship with climate. Annales de la Société entomologique de France 45: 470-486. https:// doi.org/10.1080/00379271.2009.10697630

Batisteli AF, Costiuc MY, Santieff IZ, Costa RO, Sarmento H, Pizo MA. 2020. Breeding biology of the Creamy-bellied Thrush (Turdus amaurochalinus) in southeast Brazil. Studies on Neotropical Fauna and Environment 55: 1-9. https://doi.org/10.1080/01650521.2020.17280 32

Borges FJA, Marini MÂ. 2010. Birds nesting survival in disturbed and protected Neotropical savannas. Biodiversity and Conservation 19: 223-236. https://doi. org/10.1007/s10531-009-9718-z

Duarte, AF. 2006. Aspectos da climatologia do Acre, Brasil, com base no intervalo 1971-2000. Revista. Brasileira de Meteorologia 21: 308-317.

Dyrcz A. 1991. Observations on nesting and nestling growth in the Rusty-margined Flycatcher Myiozetetes cayanensis in southeastern Peru. Bulletin of the British Ornithologists' Club 111: 33-35.

Dyrcz A. 2002. Breeding ecology of the Social (Myiozetetes similis) and Rusty-margined (M. cayanensis) flycatchers at Barro Colorado island, Republic of Panama. Ornitologia Neotropical 13: 143-151.

Dyrcz A, Flinks H. 2003. Nestling food of the congeneric and sympatric Rusty-margined and Social flycatchers. Journal of Field Ornithology 74:157-165. https://doi. org/10.1648/0273-8570-74.2.157

Frith CB, Frith DW. 1985. Seasonality of insect abundance in an Australian upland tropical rainforest. Australian Journal of Ecology 10: 237-248. https://doi. org/10.1111/j.1442-9993.1985.tb00886.x

Gan MA, Kousky VE, Ropelewski CF. 2004. The South America monsoon circulation and its relationship to rainfall over West-Central Brazil. Journal of Climate 17: 47-66. https://doi.org/10.1175/15200442(2004)017<0047:TSAMCA>2.0.CO;2

Guilherme E. 2001. Comunidade de aves do Campus e Parque Zoobotânico da Universidade Federal do Acre, Brasil. Tangara. 1: 57-73.

Guilherme E. 2016. Aves do Acre. Ed. Edufac (Editora da Universidade Federal do Acre), Rio Branco. 897 p.

Guilherme E, Lima JM. 2019. An update on the breeding biology and biometry of Hauxwell's Thrush (Turdus hauxwelii) from lowland southwestern Brazilian Amazon. Ornitologia Neotropical 30: 232-239.

Haverschmidt F. 1961. Nests of Empidonomus varius, Pitangus lictor, and Myiozetetes cayanensis. Auk. 78: 276-278. https://doi.org/10.2307/4082161

Haverschmidt F. 1971. Notes on the life history of the Rustymargined Flycatcher in Surinam. Wilson Bulletin 83: 124-128.
Hellebrekers WPJ. 1942. Revision of the Penard oölogical collection from Surinam." Zoologische Mededeelingen 24: $240-275$.

Heming NM, Greeney HF, Marini MÂ (2013) Breeding biology research and data availability for New World flycatchers. Natureza \& Conservação 11:54-58. https://doi. org/10.4322/natcon.2013.009

Jahn AE, Bejarano V, Guzmán MB, Brown LM, Provinciato ICC Cereghetti J, Cueto VR, Giraldo JI, Gómez-Bahamon V, Husak MS, LePage HK, MacPherson M, Marini MA, Pizo MA, Quickle A, Roeder DV, Sarasola JH, Tuero DT. 2017. Molt while breeding? Lessons from New World Tyrannus flycatchers. Journal of Ornithology 158: 10611072. https://doi.org/10.1007/s10336-0171464-5

Jehle G, Yackel AA, Savidge JA, Skagen SK. 2004. Nest survival estimation: a review of alternatives to the Mayfield estimator. Condor. 106: 472-484. https://doi. org/10.1093/condor/106.3.472

Johnson EI, Wolfe JD, Ryder TB, Pyle P. 2011. Modifications to a molt-based ageing system proposed by Wolfe et al. (2010). Journal of Field Ornithology 82: 422-424. https://doi.org/10.1111/j.1557-9263.2011.00345.x

Kennard, JH. 1975. Longevity Records of North American Birds. Bird-Banding. 46: 55-73. https://doi. org $/ 10.2307 / 4512096$

Kishimoto-Yamada K, Itioka T. 2015. How much have we learned about seasonality in tropical insect abundance since Wolda (1988)? Entomological Science 18: 407419. https://doi.org/10.1111/ens.12134

Klimkiewicz MK, Futcher AG. 1989. Longevity Records of North American Birds Supplement 1 (Registros de longevidad en aves de Norte América: Primer Suplemento). Journal of Field Ornithology 60: 469-494.

Lentino ML, Bonaccorso E, García MA, Fernández EA, Rivero R, Portas C. 2003. Longevity records of wild birds in the Henri Pittier National Park, Venezuela. Ornitologia Neotropical 14: 545-548.

Lima J, Guilherme E. 2020. Breeding biology and biometrics of Silver-beaked Tanager Ramphocelus carbo connectens in south-west Brazilian Amazonia. Bulletin of the British Ornithologists' Club 140: 170-181. https:// doi.org/10.25226/bboc.v140i2.2020.a8

Marini MÂ, Rodrigues SS, Silveira MB, Greeney HF. 2012. Reproductive biology of Synallaxis albescens (Aves: Furnariidae) in the Cerrado of central Brazil. Biota Neotropica 12: 1-4. https://doi.org/10.1590/S167606032012000400029

Martin TE. 2004. Avian life-history evolution has an eminent past: does it have a bright future? Auk. 121: 289-301. https://doi.org/10.2307/4090393

Mayfield H. 1961. Nesting success calculated from exposure. Wilson Bulletin 73: 255-261.

Meneses-Filho LCL, Ferraz PA, Pinha JFM, Ferreira LA, Brilhante NA. 1995. Comportamento de 24 espécies arbóreas tropicais madeireiras introduzidas no Parque Zoobotânico de Rio Branco Acre, vol. 1. Ed. Edufac, Rio Branco.

Mezquida ET, Marone L. 2001. Factors affecting nesting success of a bird assembly in the central Monte Desert, Argentina. Journal of Avian Biology 32: 287-296. https:// doi.org/10.1111/j.0908-8857.2001.320401.x 
Mobley J, Kirwan GM. 2020. Rusty-margined Flycatcher (Myiozetetes cayanensis), version 1.9 In Birds of the world (J. del Hoyo, A. Elliott, J. Sargatal, D.A. Christie, and E. de Juana, Editors. Cornell Lab of Ornithology, Ithaca, NY, USA. https://doi.org/10.2173/bow.rumfly1.01

Oniki Y, Willis EO. 1983. A study of breeding birds of the Belém area, Brazil: VI Tyrannidae. Ciência e Cultura 35: 1880-1885.

Oniki Y, Willis, E. O. 2001. A contagem do número de dias para a incubação e da criação de jovens altriciais no ninho: a importância da padronização. Atualidades Ornitológicas 100: 2 .

Pascoal W, Dantas S, Weber L, Duks C. 2016. Levantamento preliminar da avifauna do Campus da EMVZ da Universidade Federal do Tocantins, Araguaína - TO, com observações sobre a reprodução de algumas espécies. Atualidades Ornitológicas 189: 45-56.

Penny ND, Arias JR, Schubart HOR. 1978. Tendências populacionais da Fauna de coleópteros do solo sob floresta de terra firme na Amazônia. Acta Amazonica 8: 259-265. https://doi.org/10.1590/1809-43921978082259

Piacentini VQ Aleixo A., Agne CE, Maurício GN, Pacheco JF, Bravo GA, Brito GRR, Naka LN, Olmos F, Posso S, Silveira LF, Betini GS, Carrano E, Franz I, Lees AC, Lima LM, Pioli D, Schunck F, Amaral FR, Bencke GA, Cohn-Haft M, Figueiredo LFA, Straube FC, Cesari E. 2015. Annotated checklist of the birds of Brazil by the Brazilian Ornithological Records Committee / Lista comentada das aves do Brasil pelo Comitê Brasileiro de Registros Ornitológicos. Revista Brasileira de Ornitologia 23: 91-298. https://doi.org/10.1007/BF03544294

Pinho JB, Marini MÂ. 2014. Birds' nesting parameters in four forest types in the Pantanal wetland. Brazilian Journal of Biology 74: 890-898. https://doi.org/10.1590/15196984.08713

Proctor NS, Lynch PJ. 1993. Manual of ornithology. Avian structure \& function. Yale Univ. Press, New Haven, CT.

R Development Core Team. 2018. R: A language and environment for statistical computing. Vienna: R Foundation for Statistical Computing.

Redfern CPF. 2010. Brood-patch development and female body mass in passerines. Ringing \& Migration 25: 33-41. https://doi.org/10.1080/03078698.2010.9674412

Repennin M, Fontana CS. 2011. Seasonality of breeding, moult and fat deposition of birds in subtropical lowlands of southern Brazil. Emu. 111: 268-280. https://doi. org/10.1071/MU10018

Ricklefs RE. 1967. A graphical method of fitting equations to growth curves. Ecology. 48: 978-983. https://doi. org/10.2307/1934545

Ricklefs RE. 1976. Growth rates of birds in the humid New World tropics. Ibis. 118: 179-207. https://doi. org/10.1111/j.1474-919X.1976.tb03065.x

Ricklefs RE. 1980. "Watch-dog" behaviour observed at the nest of a cooperative breeding bird, the Rufous-margined Flycatcher Myiozetetes cayanensis. Ibis. 122: 116118. https://doi.org/10.1111/j.1474-919X.1980. tb00880.x

Rodrigues JMG. 1992. Abundância e distribuição vertical de coleópteros do solo em capoeira de terra firme na região de Manaus - AM, Brasil. Acta Amazonica 22: 323-333. https://doi.org/10.1590/1809-43921992223333
Saether, B. E. 1985. Variation in reproductive traits in European passerines in relation to nesting site: allometric scaling to body weight or adaptive variation? Oecologia. 68: 7-9. https://doi.org/10.1007/BF00379464

Santos E, Guilherme E. 2017. Biometry and body weight of two sympatric Myiozetetes in an urban area of southwestern Brazilian Amazonia. Ornithological Congress of the Americas. Book of Abstracts. 228-229.

Scholer MN, Merkord CL, Londoño GA, Jankowski JE. 2018 Minimum longevity estimates for some Neotropical landbirds of southeastern Peru. Wilson Journal of Ornithology 130: 818-823. https://doi.org/10.1676/17095.1

Schulenberg TS, Stotz DF, Lane DF, O'Neill JP, Parker III TA. 2010. Birds of Peru (Revised and Updated Edition). New Jersey: Princeton University Press, 664p.

Sibley DA. 2010. Aves: guía básica de identificación. Ed. Corbidi, Lima.

Sick H. 1997. Ornitologia brasileira. Ed. Nova Fronteira, Rio de Janeiro.

Silva JMC, Lima MFC, Marceliano MLV. 1990. Pesos de aves de duas localidades na Amazônia Oriental. Ararajuba. 1: 99-104.

Silveira M. 1999. Ecological aspects of bamboo-dominated forest in southwestern Amazonia: An ethnoscience perspective. Ecotropica. 5: 213-2016.

Simon JE, Pacheco S. 2005. On the standardization of nest descriptions of Neotropical birds. Revista Brasileira de Ornitologia 13: 143-154.

Skutch AF. 1960. Life histories of Central American birds II. Pacific Coast Avifauna 34. Cooper Orn. Soc., Berkeley, CA.

Skutch AF. 1985. Nesting Success, and predation on nests of Neotropical birds, reviewed. Ornithological Monographs 36: 575-594. https://doi.org/10.2307/40168306

Solano-ugalde A, Arcos-Torres A, Greeney HF. 2007. Additional breeding records for selected avian species in northwest Ecuador. Boletín SAO. 17(1): 17-25.

Suárez-Rodríguez M, Montero-Montoya RD, Garcia CM. 2017. Anthropogenic nest materials may increase breeding costs for urban birds. Frontiers in Ecology and Evolution 5: 1-10. https://doi.org/10.3389/ fevo.2017.00004

Tewksbury JJ, Anderson JGT, Bakker JD, Billo TJ, Dunwiddie PW, Groom MJ, Hampton SE, Herman SG, Levey DJ, Machnicki NJ, Rio CMD, Power ME, Rowell K, Salomon AK, Stacey L, Trombulak SC, Wheeler TA. 2014. Natural History's Place in Science and Society. BioScience. 64: 300-310. https://doi.org/10.1093/biosci/biu032

Turnhout E, Lawrence A, Turnhout S (2016) Citizen science networks in natural history and the collective validation of biodiversity data. Conservation Biology 30:532-539. https://doi.org/10.1111/cobi.12696

Verea C. 2018. Some Venezuelan wild bird species that box against their own reflections. Revista Brasileira de Ornitologia 26: 192-195. https://doi.org/10.1007/ BF03544428

Wikiaves. 2020. A enciclopédia das aves do Brasil. http://www. wikiaves.com.br/ (accessed June 2020).

Xiao H, Hu Y, Lang Z, Fang B, Guo W, Zhang Q, Pan X, Lu X (2017) How much do we know about the breeding biology of bird species in the world? Journal of Avian Biology 48:513-518. https://doi.org/10.1111/jav.00934 
Agradecimientos / Acknowledgments:

To CNPq for providing JL with an undergraduate research stipend, and to the director of the UFAC Zoobotanical Park for permission to conduct research there. To all members of the UFAC ornithology laboratory for logistical support during field work. To the Centro Nacional de Pesquisa e Conservação de Aves Silvestres (CEMAVE / ICMBio), for providing the bands used in project 1099.

\section{Conflicto de intereses / Competing interests:}

No potential conflict of interest was reported by the authors.

Rol de los autores / Authors Roles:

$J \mathrm{~L}$ performed data collection, JL and EG wrote the work.

\section{Fuentes de financiamiento / Funding:}

This work was supported by Conselho Nacional de Desenvolvimento Científico eTecnológico (CNPq) [800217/20136; 800249/20143].

Aspectos éticos / legales; Ethics / legals:

Observational information did not require permits specific. Authors declare that they did not violate or omit ethical or legal norms in this research. 